\title{
Angiogenic factors in relation to embryo implantation
}

\author{
Azadeh Bagheri ${ }^{1}$, Yousef Rezaei Chianeh ${ }^{1}$, Pratap Kumar ${ }^{2}$, Pragna Rao $^{1 *}$
}

\begin{abstract}
${ }^{1}$ Department of Biochemistry, Kasturba Medical College, Manipal University, Manipal-576104, Karnataka, India
${ }^{2}$ Department of Obstetrics \& Gynecology, Kasturba Medical College, Manipal University, Manipal-576104, Karnataka, India
\end{abstract}

Received: 16 October 2014

Accepted: 1 November 2014

\author{
*Correspondence: \\ Dr. Pragna Rao, \\ E-mail: pragna.rao@manipal.edu,drpragnarao@gmail.com
}

Copyright: ( $)$ the author(s), publisher and licensee Medip Academy. This is an open-access article distributed under the terms of the Creative Commons Attribution Non-Commercial License, which permits unrestricted non-commercial use, distribution, and reproduction in any medium, provided the original work is properly cited.

\begin{abstract}
Disturbances in uterine blood supply are associated with higher perinatal morbidity and mortality caused by preterm delivery, preeclampsia or intrauterine growth restriction. Adaptation of the uterine vasculature to the rising needs of the fetus occurs through both vasodilation and development of new vessels. Angiogenesis is the process of neovascularization from pre-existing blood vessels in response to hypoxic condition of tissues. The endometrium, decidua and placenta are rich sources of angiogenic growth factors. In general, the angiogenic process is initiated by growth factors such as VEGF, placental growth factor (PIGF) or bFGF. Through a complex signal transduction machinery mediated by respective receptor-tyrosine kinases, an increase in the permeability of the maternal vessels is achieved to permit growth and invasion of endothelial cells. Their chemotactic migration, formation of a vessel lumen, and functional maturation of new capillaries complete the angiogenic process that involves the expression of specific adhesion receptors and extracellular matrix-degrading proteases. During vasculogenesis, endothelial progenitor cells--angioblasts--form a primitive vascular network. This process occurs mainly during fetal development, although recruitment of angioblasts from bone marrow and peripheral blood in response to ischemic insult have been described in adults. In this review article we have described a recent complication related to angiogenic involvement in embryo implantation.
\end{abstract}

Keywords: HIF-1 (Hypoxia inducible factor-1), VEGF (vascular endothelial growth factor), Embryo implantation, MMP (matrix metalloprotease)

\section{INTRODUCTION}

Miscarriage is defined by the World Health Organization (WHO) as the premature loss of a fetus up to 20 weeks of pregnancy and weighing up to $500 \mathrm{~g} .{ }^{1}$ Overall, about 12$15 \%$ of clinically recognized pregnancies end in miscarriage, ${ }^{2}$ with the frequency increasing with rising maternal age.

There are numerous factors involved in early pregnancy loss, increase maternal age is considered to be one of reason for abortion. It is estimated that approximately 8 to 20 pregnancies lead to spontaneous abortion before the 20 weeks of gestation. ${ }^{3-5}$ The investigation has shown that the probability of a pregnancy loss after the 15 weeks of gestation decreasing drastically, but still various factors is detrimental for a successful pregnancy like, age of gestation as well as ethnicity. ${ }^{6}$ But around 26 percent of pregnancy loss are an unknown cases, ${ }^{3-5,7,8}$ that majority of them are happening in early pregnancy. A study has shown that a history of irregularity of menstruation and the heavy bleeding during each cycle before pregnancy increases a possibility for an abortion for a considerable number of times. ${ }^{9}$

There are various factors involved in different types of miscarriage, but complication related to placenta has attracted more attention. ${ }^{10-12}$ In this review article we 
surveyed a role of angiogenic factors in embryo implantation.

When a pregnancy fails, there is always an underlying medical condition most often autoimmune disease. Hypoxic condition such as iron deficiency anemia causes a transcription of HIF-1 (Hypoxia inducible factor-1) to rapidly accumulate transactivate hundreds of genes, including angiogenic growth factor, and, the receptors for growth factors, a protease that are present in the ECM, like MMPs. Activation of these growth factors that is being stored in ECM is the requirement of angiogenesis and initiated by MMPs in extracellular segment of the cell.

Copper is an essential trace element for all the living organisms and is one the key requirement for angiogenesis. Hence the activity of several angiogenic factors directly or indirectly depend upon it. Copper and oxygen tension are a key regulator of the VEGF gene expression and many other factors that are involved in the process of cancer cell mutation and secretion of many hormones, like estrogen, thyroid hormones. Even though angiogenic factors are fundamental requirements for process of formation of new blood vessel that is referred as pathological angiogenesis but hypoxic condition is triggering factors for synthesis of growth factors through the formation of Hypoxia Inducible Factor (HIF). Through many experimental evident, it is evident that HIF is involved in transcription of the gene that mediate angiogenesis. Presently HIF is classified into HIF$\alpha$ (HIF-1, HIF-2, and HIF-3) and HIF $\beta$ (HIF-1, HIF-2, and HIF-3) and transcription of aforementioned factors require oxygen tension.

Copper can cause stabilization of HIF-1 $\alpha$. There are different sequence of gene requires for activation of HIF$1 \alpha$ and result in synthesis of HIF- $1 \alpha$ and then HIF-1 $\alpha$ binds to the sequence of the gene and result in synthesis of VEGF and many different family of VEGF. Hypoxic pathways other than VEGF may also regulate matrix metalloproteinase (MMPs). Reduced oxygen levels stimulate MMP-9 expression in a highly invasive, metastatic breast cancer cell line, but this process may have a different feature in prostate cancer.

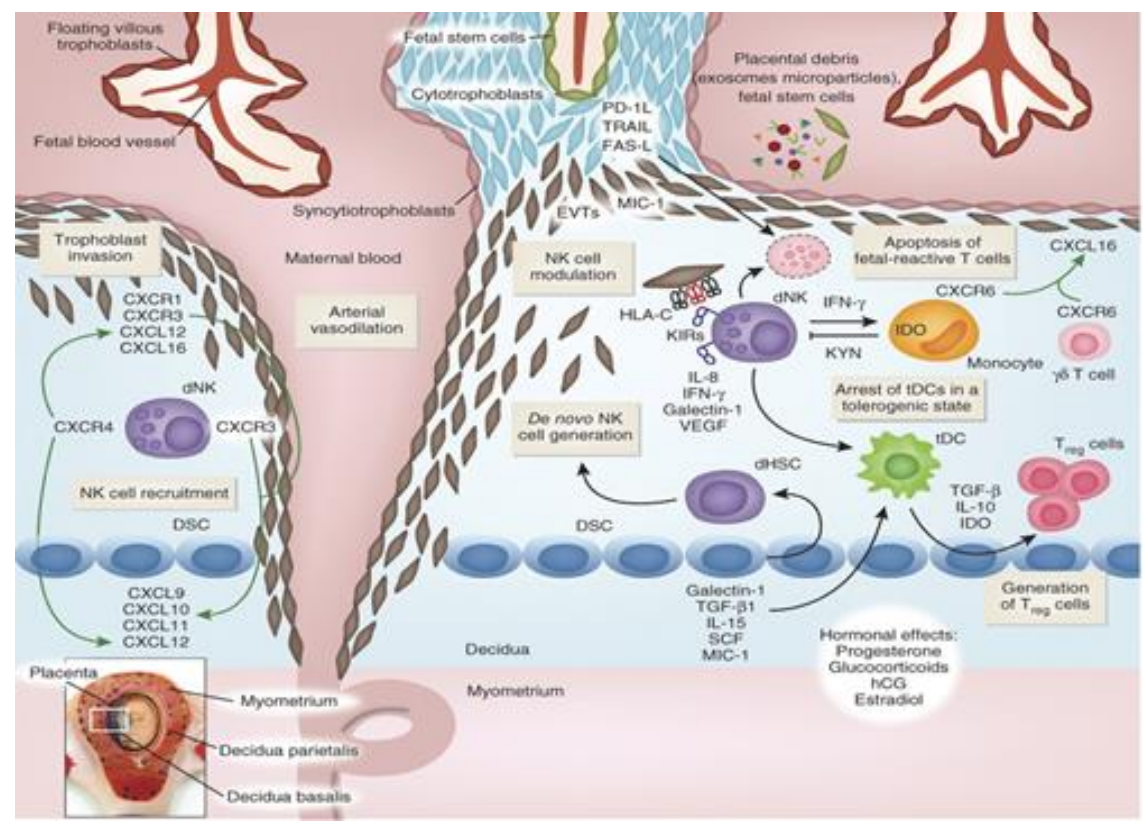

Figure 1: Key pathways involved in immune tolerance toward fetus during the first trimester of human pregnancy.

Anchoring villous trophoblasts attach to the decidua and further differentiate into syncytiotrophoblasts, cytotrophoblasts and EVTs. Floating villous trophoblasts carrying fetal blood vessels are bathed in maternal blood and can shed placental exosomes, microparticles and fetal stem cells. Expression of chemokine receptors and their cognate ligands orchestrate the invasion of EVTs and migration of maternal leukocytes into the decidua. EVTs establish direct contact with DSCs and maternal leukocyte populations. Via IL-15 and stem cell factor (SCF) production by DSCs, de novo generation of dNK cells occurs locally upon differentiation of tissue resident lin ${ }^{\text {neg }} \mathrm{CD} 45^{+} \mathrm{CD} 34^{+}$decidual hematopoietic stem cells (dHSCs). Macrophage inhibitory cytokine-1 (MIC-1), TGF- $\beta 1$ and galectin-1 production by DSCs and/or NK cells promotes the arrest of decidual DCs in a tolerogenic state (tDCs), and NK cell-derived galectin-1 induces apoptosis of activated T cells in vitro. ${ }^{13}$ Upon dNK cell-derived IFN- $\gamma$ secretion, the enzymatic expression of IDO in human decidual CD14+ monocytes, another predominant decidual cell subset of the innate immune system, is upregulated in vitro. Monocytederived IDO may enhance fetal tolerance via the generation of CD4+ Treg cells or selective apoptosis of effector $\mathrm{T}$ cells. ${ }^{14}$ Synergistically with tDCs and monocytes, dNK cells promote the generation of Treg cells and apoptosis of effector $\mathrm{T}$ cells. Decidualization is modulated by pregnancy hormones such as progesterone. The anatomical position where these maternal adaptations occur is indicated by the white square in the insert of a pregnant uterus. hCG, human chorionic gonadotropin; KYN, kynurenine; VEGF, vascular endothelial growth factor. ${ }^{15}$ 
HIF-1 $\alpha$ rapidly accumulates and cause activation of number of genes responsible for the synthesis of angiogenic growth factors and receptors and proteases that are present in extracellular part of the cell such as matrix metalloproteinases (MMPs) (MMP-9, HIF-1 $\alpha$ in breast cancer). MMPs are endopeptidase that degrade most of the components of extracellular matrix (ECM), including the basement membrane. They also involved in the regulation of cell proliferation. MMPs play an important role in triggering endometrial bleeding. Similar changes in the expression and activity of MMP-2 and 9 (gelatinase A and B) are found. Anemia induces HIF-1 result in a number of physiological changes which exert direct effects on maternal health.

Numerous exogenous factor have been identified as playing a role in regulating angiogenesis, copper has been shown to have an effect on production of number of angiogenic factors including VEGF-A. Copper and copper complexes have shown to directly stimulate angiogenesis in several animal model systems, while copper chelation has shown to inhibit angiogenesis.

With respect to autoimmunity, it is represented by a bidirectional model: autoimmune disease (AIDs) can be affected by pregnancy, and, in turn, pregnancy can be affected by AIDS, mainly during the very early and vary late stages of gestation. Anti-Phospholipid Syndrome (APS) and Systemic Lupus Erythematous (SLE) are the odds that most commonly jeopardize pregnancy and potential adverse events consist of miscarriage, intrauterine fetal restriction, Congenital Heart Block (CHB) and preterm delivery.

It is widely accepted a thin endometrial thickness on transvaginal ultrasound scan is associated with a poor pregnancy rate. All women with recurrent first- trimester miscarriage and all women with one or more trimester miscarriage should be screened before pregnancy for antiphospholipid antibodies. However, even among APLP negative women, a significant proportion of recurrent miscarriage cases remain unexplained despite detailed investigation.

The role of uterine NK-cells and cytokines in recurrent miscarriage is a new concept which is being explored to explain such cases. There are two main NK-cell subsets. The major subset, approximately $95 \%$ of circulating NKcell in peripheral blood, is characterized as being CD56dimCD16+, have strong production of granzyme and perforin, and are generally associated with cytotoxicity. The remaining approximately 5\% of circulating NK-cell are CD56brightCD16- and show lower cytotoxicity and higher levels of cytokine production. Remarkably, within the developing decidua, there is another very different NK-cell subset [decidual NK (dNK) cells] that displays a cytokine secreting, highly angiogenic phenotype in humans and mice. Human dNK cells are CD56superbrightCD16-, produce VEGF, PIGF and Interleukins.

\section{COPPER AND CERULOPLASMIN}

Copper can stimulate, synthesis and proliferate many growth factors $^{16,17}$ and it has a common pathway for utilization of hypoxia to regulate VEGF-A expression. $^{16,18}$ It has been shown that growth of the blood vessels in some circumstances has some unknown etiology, subsequently it is being attributed to involvement of copper. ${ }^{19}$ Presently it has been confirmed that copper can induce the neovascularisation. It is being established that some of the inflammatory compound can stimulate blood vessel growth and in the presence of copper, leukocytes can cause release of MMPs from extracellular matrix and result in degradation of ECM. ${ }^{20}$ Copper can induce proliferation of endothelial cell and can act as a stimulatory factor for a number of angiogenic growth factors. Example: VEGF, TNF- $\alpha$, bFGF. ${ }^{21}$ Ceruloplasmin in this process act as carriers and storage form of copper and can help for the biological activity of copper by storing and by its enzymatic property.

\section{VASCULAR ENDOTHELIAL GROWTH FACTOR (VEGF)}

Currently, the VEGF family includes VEGF-A, PlGF (placenta growth factor), VEGF-B, VEGF-C, VEGF-D, VEGF-E and svVEGF (snake venom VEGF). They are a potent angiogenic element. ${ }^{22,23}$ The molecular and biological functions of each of these growth factors have been well characterized.

Human VEGF-A has at least nine subtypes due to the alternative splicing of a single gene: VEGF121, VEGF145, VEGF148, VEGF162, VEGF165, VEGF165b, VEGF183, VEGF189 and VEGF206. ${ }^{24} \mathrm{~A}$ studies have shown the involvement of VEGF receptors in embryogenesis. ${ }^{25,26}$

Any disturbance in the production of VEGF and its receptor produces an abnormal vasculogenesis and ultimately may lead to anomalies or miscarriage. ${ }^{27}$ Coordinated process of VEGF and VEGF receptor are fundamental for pre-implantation and postimplantation. $^{27,28}$

There are varieties of factors that play a crucial role in VEGF gene expression, hormones like, estrogen and hCG are shown to have modulating effect on VEGF expression on early stage of implantation. ${ }^{29}$ Both these factors involve in the expression of these genes in the endometrium as well as an embryo. Studies have shown that genetic polymorphism in this gene can lead to uncoordinated secretion of this growth factor and result in recurrent miscarriage. ${ }^{30}$ Many studies suggest that disruption of VEGF expression in early pregnancy can result in implantation failure and consequently lead to an abortion.

Implantation is the complicated mechanism that results in the developing embryo and making a contact with the 
maternal endometrium initiating the development of the placenta. Endometrial VEGF-A is found to be an important molecule regulating implantation. ${ }^{31}$

Recently the expression of VEGF-C in the endometrium and placenta found to play a critical role in implantation and successful pregnancy. ${ }^{32}$ Additionally, uterine natural killer cells (NK cells) express high levels of mRNAs for VEGF-C that adds to the liability of VEGF-C and its role in pregnancy outcome. ${ }^{33,34}$

\section{HYPOXIA INDUCED FACTOR-1 $\alpha$ (HIF-1 $\alpha)$}

In the normal condition all the cells in the body are supplied with sufficient amount of oxygen through lungs, RBC and cardiac system, oxygen is carried to the site of the cell by haemoglobin in the RBC and concentration of haemoglobin is controlled by the hormone erythropoietin that is secreted from kidney and liver. During hypoxic condition the kidney release a hormone known as EPO, that causes haematopoiesis to occur in the bone marrow and result in synthesis of RBC to compensate a lack of $\mathrm{O}_{2}$. If a hypoxia persists, it causes transcription of specific genes that result in synthesis of factors known as Hypoxia Inducible Factor (HIF). ${ }^{35,36}$ Consequently, HIF binds to the region of the gene that leads to transcription of angiogenic growth factors like, VEGF, bFGF. ${ }^{37,38}$ In pathological condition, hypoxia causes a transcription of more number of angiogenic factors that result in the formation of more number of blood vessels in the endometrium and cause thickening of endometrium that could prevent implantation and pregnancy failure but the exact mechanism by which lack of oxygen is sensed is unknown. Some studies have shown that HIF-1 $\alpha$, as an iron-containing protein, can perform this function. ${ }^{39-44}$

\section{MATRIX METALLOPROTEINASE (MMP 2,9)}

Matrix metalloproteases are secreted from ECM in response to its stimuli for degradation of ECM. Many angiogenic activators and inhibitors are stored as fragments of compound within larger molecules in the extracellular matrix, among the most studied are endostatin derived from collagen XVIII $^{45,46}$ angiostatin derived from plasminogen ${ }^{47,48}$ and tumstatin derived from type IV collagen. ${ }^{49}$

MMP-9 can be both a promoter of the angiogenic switch by releasing angiogenic stimuli from the ECM or it may act as angiogenic inhibitor by releasing angiogenic inhibitors from their parent matrix molecules. Serine protease family is another ECM protease that has a direct role in tumor angiogenesis. This is a family of plasminogen activator-plasmin system. During active angiogenesis by angiogenic growth protein, especially bFGF and VEGF, activation of plasminogen activator inhibitor type I (PAI-I) and urokinase type plasminogen activator ( $\mathrm{UPA}$ ) expression are induced and this is being implicated in tumor invasion and metastasis. ${ }^{50}$ Collagens, laminins and fibronectins are among many other proteins present in the ECM and surrounding vasculature, have pro-angiogenic properties and capable of promoting endothelial cell proliferation, survival, migration and blood vessel formation.

Furthermore, the role of MMP in stimulating tumor angiogenesis and growth is by cleaving a sequence of collagen IV that causes exposure of the pro-angiogenic sequence. $^{51}$ Non-pathological angiogenesis are finely tuned process and factors involve in controlling abnormal vessel growth like endogenous anti-angiogenesis that controls out growth of blood vessels by inhibiting the factor involve in their activation. The first angiogenic inhibitor identified was thrombospodin-1 (TSP-1). ${ }^{52}$ It is a protein family of five large extracellular glycoprotein. Thrombospodin- 1 and -2 by binding to collagen and fibronectin can affect ECM structure and modulate its protease activity such as MMP-9 and plasmin. Cryptic fragments of ECM are among the other angiogenic inhibitors. The degradation of a C- terminal fragment of collagen XVIII lead to formation of endostatin, is one of the most studied anti-angiogenic factor of ECM.

Chronic uterine inflammation is considered to be a major cause of a RIF (Recurrent implantation failure) and high MMP activity. Among the multiple MMPs produced by the human placenta, MMP-2 and -9 have been assigned a key roles in promoting the invasive capacity of CTBs. ${ }^{53-55}$ The reduced MMP-9 activity in CTBs isolated from preeclamptic placentas together with a reported reduced invasive capacity of CTBs in vitro after specific inhibition of MMP-2 and -9 further underline the important role of these two proteolytic enzymes during early implantation. ${ }^{56}$

HCG is an important signal of peri-implantation of embryos $^{57}$ and has been shown to regulate the invasion of CTB. ${ }^{58}$ The stimulatory effect of hCG on trophoblastic MMP-2 and -9 , is known. It is observed that hCG has a short-time regulatory effect on MMPs and this could be due to a direct influence on the secretion of presynthesized MMPs.

\section{HORMONAL REGULATION OF ANGIOGENESIS}

Studies have shown a inducing and the proliferating effect of $17 \beta$-estradiol on NK-cell. ${ }^{59}$ This hormone result in migration of peripheral NK-cell to endothelial cells of endometrium and result in the cytotoxic effect of NK-cell in human endometrium. ${ }^{60}$ Estrogen, progesterone and prolactin can stimulate the synthesis and production of number of angiogenic growth factor like, VEGF, etc. Consequently, these growth factors result in proliferation of NK-cell and as a result of this NK-cell secrete a number of cytokines such as, VEGF-A, C, MMP 2-9, as well as INF- $\Upsilon$ that result in the development of the placenta and promote local immunomodulation. Prolactin is involved in modulation of NK-cell activity and result in a decrease or normalization of NK-cell numbers. ${ }^{61,62}$ HCG has been identified to have an important role in 
inducing angiogenesis. ${ }^{63,64}$ In an in vivo study shown that hCG are capable of stimulating neovascularisation in several classical models. ${ }^{63,64}$

\section{DISCUSSION}

Human placenta is more exceptional than the other mammalian because human placentation is characterized by firmly embedding itself in the endometrium. During normal pregnancy, early growth of fetus occur in less oxygen concentration. ${ }^{65,66}$ This phenomenon is known as physiological hypoxia that prevent the fatal effects from reactive oxygen species.

Constant $\mathrm{O}_{2}$ concentration between uterine endometrium and placental tissue plays a fundamental role in developing foetus and angiogenesis. ${ }^{67,68}$ Among all pregnancy related disorder, the implantation failure considers to be important due to loss of endometrial receptivity resulted from poor or abnormal angiogenesis. Development of the blood vessels in the endometrium through a regulated angiogenesis in the endometrium is an essential requirement for fetal implantation. Soon after implantation, development of the placenta is required for transportation of $\mathrm{O}_{2}$ and nutrient to the embryo. These two physiologically coordinated processes are needed for embryo implantation and growth and different from those occurring in tumors. ${ }^{68}$ These results support the fact that angiogenesis is an important element for normal implantation and indicates the importance of the vasculature in early stages of pregnancy.

Conversely, if vascularity in the endometrium occurs during a late stage of pregnancy can have pathophysiological consequences leads to miscarriage. ${ }^{15}$ This could be as a result of regulated factors that are participated in secreting a factor in different stage of pregnancy that modulate a growth factor formation and ultimately have an effect on fetal growth and maternal health. ${ }^{15}$ There are studies that support involvement of disturbed angiogenesis responsible in recurrent pregnancy loss. ${ }^{69}$ Studies show that a different pattern of expression of angiogenic growth factor is involved in recurrent miscarriage. $^{70}$

As with most human studies, whether the unregulated genetic expression of angiogenic growth factor were responsible for a nature of miscarriages is difficult to determine with certainty. There are two mechanisms involved in the formation of blood vessels: vasculogenesis and angiogenesis. ${ }^{71}$ Vasculogenesis occur during mainly fetal growth and development. ${ }^{72,73}$ Angiogenesis usually consider as a pathological form of the blood vessel formation that result in tumor formation, the process occurs from accumulation of growth factor such as VEGF and etc., ${ }^{74}$ but physiological angiogenesis are involved in wound healing, bone fracture and in embryo implantation in concert with vasculogenesis. ${ }^{75}$

Therapeutic approach with respect to angiogenesis have revolutionized a Field of cancer treatment, heart disease,
Cerebrovascular disease. ${ }^{76,77}$ Anti-angiogenic treatment appears to be a good strategy for treatment of cancer. ${ }^{75}$ In common term, angiogenesis are initiated by secreting a growth factor like, VEGF, TNF $\alpha, \mathrm{bFGF}$, etc. ${ }^{78}$ These factors cause the differentiation of epithelial cell and degradation of ECM by activating a proteases that are present and stored in ECM. ${ }^{79,80}$

This review article aim to survey a recent development in the field of angiogenesis with respect to embryo implantation.

\section{ACKNOWLEDGMENTS}

We thank Dr. Pradeep Kumar, Dean, KMC, Manipal for providing resources and guiding us to complete this project.

\section{Funding: No funding sources \\ Conflict of interest: None declared \\ Ethical approval: Not required}

\section{REFERENCES}

1. WHO. Definitions and indicators in family planning, maternal and child health and reproductive health. In: WHO, eds. WHO Regional Strategy on Sexual and Reproductive Health. Geneva: World Health Organization, 2001: 1-14.

2. Zinaman MJ, Clegg DE, Brown CC, O'Connor J, Selevan SG. Estimates of human fertility and pregnancy loss. Fertil Steril. 1996;65:503-9.

3. Regan L, Rai R. Epidemiology and the medical causes of miscarriage. Baillieres Best Pract Res Clin Obstet Gynecol. 2000;14:839.

4. Harlap S, Shiono PH. Alcohol, smoking, and incidence of spontaneous abortions in the first and second trimester. Lancet. 1980;2:173.

5. Wang X, Chen C, Wang L, Chen D, Guang W, French J. Conception, early pregnancy loss, and time to clinical pregnancy: a population-based prospective study. Fertil Steril. 2003;79:577.

6. Wyatt PR, Owolabi T, Meier C, Huang T. Agespecific risk of fetal loss observed in a second trimester serum screening population. Am J Obstet Gynecol. 2005;192:240.

7. Boklage CE. Survival probability of human conceptions from fertilization to term. Int $\mathrm{J}$ Fertil. 1990;35:75,79.

8. Lohstroh PN, Overstreet JW, Stewart DR, Nakajima ST, Cragun JR, Boyers SP, et al. Secretion and excretion of human chorionic gonadotropin during early pregnancy. Fertil Steril. 2005;83:1000.

9. Promislow JH, Baird DD, Wilcox AJ, Weinberg CR. Bleeding following pregnancy loss before 6 weeks' gestation. Hum Reprod. 2007;22:853.

10. Jauniaux E, Poston L, Burton GJ. Placental-related diseases of pregnancy: involvement of oxidative stress and implications in human evolution. Hum Reprod Update. 2006;12:747-55. 
11. Jauniaux E, Van Oppenraaij RH, Burton GJ. Obstetric outcome after early placental complications. Curr Opin Obstet Gynecol. 2010;22:452-7.

12. Jauniaux E, Watson AL, Hempstock J, Bao YP, Skepper JN, Burton GJ. Onset of maternal arterial blood flow and placental oxidative stress; a possible factor in human early pregnancy failure. Am J Pathol. 2000;157:2111-22.

13. Vacca P, Cantoni C, Vitale M, Prato C, Canegallo F, Fenoglio D, et al. Crosstalk between decidual NK and CD14+ myelomonocytic cells results in induction of Tregs and immunosuppression. Proc Natl Acad Sci USA. 2010;107:11918-23.

14. Petra C. Arck, Kurt Hecher. Fetomaternal immune cross-talk and its consequences for maternal and offspring's health. Nature Med. 2013 May;19(5):548-56.

15. Reynolds LP, Caton JS, Redmer DA, Grazul-Bilska AT, Vonnahme KA, Borowicz PP, et al. Evidence for altered placental blood flow and vascularity in compromised pregnancies. J Physiol. 2006;572:51-8.

16. Khandhadiya PK, Yousef Rezaei Chianeh, R. Pragna. Role of serum copper and ceruloplasmin level in patients with dysfunctional uterine bleeding. Int J Reprod Contracept Obstet Gynecol. 2014;3(2):333-4.

17. Harris ED. A requirement for copper in angiogenesis. Nutr Rev. 2004;62(2):60-4.

18. Girling JE, Rogers PA. Recent advances in endometrial angiogenesis research. Angiogenesis. 2005;8(2):89-99.

19. McAuslan BR, Reilly W. Endothelial cell phagokinesis in response to specific metal ions. Exp Cell Res. 1980;130:147-57.

20. Lin MT, Chen YL. Effect of copper ion on collagenase release. Invest Opthomol Vis Sci. 1992;33:558-63.

21. Afshan Rafi, D. Ramkrishna, K. Sabitha, S. Mohaty, Pragna Rao. Serum copper and vascular endothelial growth factor (VEGF) in dysfunctional uterine bleeding. Am J Biochem Mol Biol. 2011;1(3):28490 .

22. Takahashi H, Shibuya M. The vascular endothelial growth factor (VEGF)/VEGF receptor system and its role under physiological and pathological conditions. Clin Sci (Lond). 2005;109:227-41.

23. Tammela T, Enholm B, Alitalo K, Paavonen K. The biology of vascular endothelial growth factors. Cardiovasc Res. 2005;65:550-63.

24. Gluzman-Poltorak Z, Cohen T, Herzog Y, Neufeld G. Neuropilin-2 and neuropilin-1 are receptors for the 165-amino acid form of vascular endothelial growth factor (VEGF) and of placenta growth factor2 , but only neuropilin-2 functions as a receptor for the 145-amino acid form of VEGF. J Biol Chem. 2000;275:18040-5.

25. Fong GH, Rossant J, Gertsenstein M, Breitman ML. Role of the Flt-1 receptor tyrosine kinase in regulating the assembly of vascular endothelium. Nature. 1995;376:66-70.

26. Shalaby F, Rossant J, Yamaguchi TP, Gertsenstein $\mathrm{M}, \mathrm{Wu}$ XF, Breitman ML, et al. Failure of bloodisland formation and vasculogenesis in Flk-1deficient mice. Nature. 1995;376:62-6.

27. Bagheri A, Chianeh YR, Rao P. Role of angiogenic factors in recurrent pregnancy loss. Int $\mathrm{J}$ Reprod Contracept Obstet Gynecol. 2013;2:497-502.

28. Das SK, Chakraborty I, Wang J, Dey SK, Hoffman LH. Expression of vascular endothelial growth factor (VEGF) and VEGF-receptor messenger ribonucleic acids in the peri-implantation rabbit uterus. Biol Reprod. 1997;56:1390-9.

29. Evans PW, Wheeler T, Anthony FW, Osmond C. A longitudinal study of maternal serum vascular endothelial growth factor in early pregnancy. Hum Reprod. 1998;13:1057-62.

30. Papazoglou D, Galazios G, Papatheodorou K, Liberis V, Papanas N, Maltezos E, et al. Vascular endothelial growth factor gene polymorphisms and idiopathic recurrent pregnancy loss. Fertil Steril. 2005;83:95963.

31. Smith SK. Angiogenesis and implantation. Hum Reprod. 2000;15(Suppl 6):59-66.

32. Schiessl B, Innes BA, Bulmer JN, Otun HA, Chadwick TJ, Robson SC, et al. Localization of angiogenic growth factors and their receptors in the human placental bed throughout normal human pregnancy. Placenta. 2009;30:79-87.

33. Li XF, Charnock-Jones DS, Zhang E, Hiby S, Malik $\mathrm{S}$, Day K, et al. Angiogenic growth factor messenger ribonucleic acids in uterine natural killer cells. J Clin Endocrinol Metab. 2001;86:1823-34.

34. Lash GE, Schiessl B, Kirkley M, Innes BA, Cooper A, Searle RF, et al. Expression of angiogenic growth factors by uterine natural killer cells during early pregnancy. J Leukoc Biol. 2006;80:572-80.x

35. Jones A, Fujiyama C, Blanche C, Moore JW, Fuggle $\mathrm{S}$, Cranston D, et al. Relation of vascular endothelial growth factor production to expression and regulation of hypoxia-inducible factor-1 alpha and hypoxia inducible factor- 2 alpha in human bladder tumors and cell lines. Clin Cancer Res. 2001;7:126372.

36. Iyer NV, Kotch LE, Agani F, Leung SW, Laughner $\mathrm{E}$, Wenger $\mathrm{RH}$, et al. Cellular and developmental control of $\mathrm{O}_{2}$ homeostasis by hypoxia-inducible factor 1 alpha. Genes Dev 1998;12:149-62.

37. Dachs GU, Tozer GM. Hypoxia modulated gene expression: angiogenesis, metastasis and therapeutic exploitation. Eur J Cancer. 2000;36:1649-60.

38. Tsuzuki Y, Fukumura D, Oosthuyse B, Koike C, Carmeliet P, Jain RK. Vascular endothelial growth factor (VEGF) modulation by targeting hypoxia inducible factor-1alpha hypoxia response element VEGF cascade differentially regulates vascular response and growth rate in tumors. Cancer Res. 2000;60:6248-52. 
39. Forsythe JA, Jiang BH, Iyer NV, Agani F, Leung $\mathrm{SW}$, Koos RD, et al. Activation of vascular endothelial growth factor gene transcription by hypoxia-inducible factor 1 . Mol Cell Biol. 1996;16:4604-13.

40. Chianeh YR, Rao P. Molecular and hormonal regulation of angiogenesis in proliferative endometrium. Int J Res Med Sci. 2014;2:1-9.

41. Ryan HE, Lo J, Johnson RS. HIF-1 alpha is required for solid tumor formation and embryonic vascularization. EMBO (Eur Mol Biol Organ) J. 1998;17:3005-15.

42. Srinivas V, Zhu X, Salceda S, Nakamura R, Caro J. Hypoxia-inducible factor 1alpha (HIF-1alpha) is a non-heme iron protein. Implications for oxygen sensing. J Biol Chem. 1998;273:18019-22.

43. Chambers WH, Amoscato AA, Smith MS, Kenniston TW, Herberman RB, Appasamy PM. Prolactin receptor expression by rat $\mathrm{NK}$ cells. Nat Immun. 1995; $14: 145-56$

44. Richard DE, Berra E, Pouyssegur J. Nonhypoxic pathway mediates the induction of hypoxia-inducible factor 1alpha in vascular smooth muscle cells. J Biol Chem. 2000;275:26765-71.

45. O'Reilly MS, Boehm T, Shing Y, Fukai N, Vasios G, Lane WS, et al. Endostatin: an endogenous inhibitor angiogenesis and tumor growth. Cell. 1997;88(2):277-85.

46. Ferreras M, Felbor U, Lenharda T, Olsen BR, Delaissé JM. Generation and degradation of human endostatin protein by various proteinases. FEBS Lett. 2000;486(3):247-51.

47. Dong Z, Kumar R, Yang X, Fidler IJ. Macrophagederived metalloelastase is responsible for the generation of angiostatin in Lewis lung carcinoma. Cell. 1997;88(6):801-10.

48. Cornelius LA, Nehring LC, Harding E, Bolanowski M, Welgus HG, Kobayashi DK, et al. Matrix metalloproteinases generate angiostatin: effect on neovascularization. J Immunol. 1998;161(12):684552.

49. Hamano Y, Zeisberg M, Sugimoto H, Lively JC, Maeshima Y, Yang C, et al. Physiological levels of tumstatin, a fragment of collagen IV alpha3 chain, are generated by MMP-9 proteolysis and suppress angiogenesis via alpha $\mathrm{V}$ beta3 integrin. Cancer Cell. 2003;3(6):589-601.

50. Pepper MS. Role of the matrix metalloproteinase and plasminogen activator-plasmin systems in angiogenesis. Arterioscler Thromb Vasc Biol. 2001;21(7):1104-17.

51. Cross MJ, Claesson-Walsh L. FGF and VEGF function in angiogenesis: signalling pathways, biological responses and therapeutic inhibition. Trends Pharmacol Sci. 2001;22(4):201-7.

52. Good DJ, Polverini PJ, Rastinejad F, Le Beau MM, Lemons RS, Frazier WA, et al. A tumor suppressordependent inhibitor of angiogenesis is immunologically and functionally indistinguishable from a fragment of thrombospondin. Proc Natl Acad Sci U S A. 1990;87(17):6624-8.

53. Bischof P, Campana A. Molecular mediators of implantation. Baillieres Best Pract Res Clin Obstet Gynecol. 2000;14:801-14.

54. Librach CL, Werb Z, Fitzgerald ML, Chiu K, Corwin $\mathrm{NM}$, Esteves RA, et al. 92-kD type IV collagenase mediates invasion of human cytotrophoblasts. J Cell Biol. 1991;113:437-49.

55. Shimonovitz S, Hurwitz A, Dushnik M, Anteby E, Geva-Eldar T, Yagel S. Developmental regulation of the expression of 72 and $92 \mathrm{kd}$ type IV collagenases in human trophoblasts: a possible mechanism for control of trophoblast invasion. Am J Obstet Gynecol. 1994; 171:832-8.

56. Isaka K, Usuda $S$, Ito $H$, Sagawa $Y$, Nakamura $H$, Nishi $\mathrm{H}$, et al. Expression and activity of matrix metalloproteinase 2 and 9 in human trophoblasts. Placenta. 2003;24:53-64.

57. Lopata A, Oliva K. Chorionic gonadotrophin secretion by human blastocysts. Hum Reprod. 1993;8:932-8.

58. Zygmunt M, Hahn D, Munstedt K, Bischof P, Lang $\mathrm{U}$. Invasion of cytotrophoblastic JEG-3 cells is stimulated by hCG in vitro. Placenta. 1998;19:58793.

59. Sorachi K, Kumagai S, Sugita M, Yodoi J, Imura H. Enhancing effect of $17 \beta$-estradiol on human NK cell activity. Immunol Lett. 1993;36:31-5.

60. Szekeres-Bartho J, Hadnagy J, Pacsa AS. The suppressive effect of progesterone on lymphocyte cytotoxicity: unique progesterone sensitivity of pregnancy lymphocytes. J Reprod Immunol. 1985;7:121-8.

61. Gerli R, Rambotti P, Nicoletti I, Orlandi S, Migliorati G, Riccardi C. Reduced number of natural killer cells in patients with pathological hyperprolactinemia. Clin Exp Immunol. 1986;64:399-406.

62. Matera L, Ciccarelli E, Cesano A, Veglia F, Miola C, Camanni F. Natural killer activity in hyperprolactinemic patients. Immunopharmacology. 1989;18:143-6.

63. Berndt S, d'Hauterive SP, Blacher S, Pequeux C, Lorquet S, Munaut $\mathrm{C}$, et al. Angiogenic activity of human chorionic gonadotropin through LH receptor activation on endothelial and epithelial cells of the endometrium. FASEB J. 2006;20:2630-2.

64. Zygmunt M, Herr F, Keller-Schoenwetter S, KunziRapp K, Munstedt K, Rao CV, et al. Characterization of human chorionic gonadotropin as a novel angiogenic factor. $\mathrm{J}$ Clin Endocrinol Metab. 2002;87:5290-6.

65. Jauniaux E, Gulbis B, Burton GJ. The human first trimester gestational sac limits rather than facilities oxygen transfer to the foetus: a review. PlacentaTrophoblast Res. 2003;24:S86-93.

66. Red-Horse K, Zhou Y, Genbacev O, Prakobphol A, Foulk R, McMaster M, et al. Trophoblast differentiation during embryo implantation and 
formation of the maternal-fetal interface. J Clin Invest. 2004;114:744-54.

67. Burton GJ. Oxygen, the Janus gas; its effects on human placental development and function. J Anat. 2009;215:27-35.

68. Torry RJ, Rongish BJ. Angiogenesis in the uterus: potential regulation and relation to tumor angiogenesis. Am J Reprod Immunol. 1992;27:1719.

69. Meegdes BH, Ingenhoes R, Peeters LL, Exalto N. Early pregnancy wastage: relationship between chorionic vascularization and embryonic development. Fertil Steril. 1988;49:216-20.

70. Vuorela P, Carpen O, Tulppala M, Halmesmaki E. VEGF, its receptors and the tie receptors in recurrent miscarriage. Mol Hum Reprod. 2000;6:276-82.

71. Poole TJ, Coffin JD. Vasculogenesis and angiogenesis: two distinct morphogenetic mechanisms establish embryonic vascular pattern. J Exp Zool. 1989;251(2):224-31.

72. Risau W, Flamme I. Vasculogenesis. Annu Rev Cell Dev Biol. 1995;11:73-91.

73. Takahashi T, Kalka C, Masuda H, Chen D, Silver M, Kearney M, et al. Ischemia- and cytokine-induced mobilization of bone marrow derived endothelial progenitor cells for neovascularization. Nat Med. 1999;5(4):434-8.
74. Flamme I, Frolich T, Risau W. Molecular mechanisms of vasculogenesis and embryonic angiogenesis. J Cell Physiol. 1997;173(2):206-10.

75. Folkman J. Angiogenesis in cancer, vascular, rheumatoid and other disease. Nat Med. 1995;1(1):27-31.

76. Hockel M, Schlenger K, Doctrow S, Kissel T, Vaupel P. Therapeutic angiogenesis. Arch Surg. 1993;128(4):423-9.

77. Thompson WD, Li WW, Maragoudakis M. The clinical manipulation of angiogenesis: pathology, side-effects, surprises, and opportunities with novel human therapies. J Pathol. 2000;190(3):330-7.

78. Folkman J, Klagsbrun M. Angiogenic factors. Science. 1987;235(4787):442-7.

79. Reynolds LP, Killilea SD, Redmer DA. Angiogenesis in the female reproductive system. FASEB J. 1992;6(3):886-92.

80. Risau W. Mechanisms of angiogenesis. Nature. 1997;386(6626):671-4.

DOI: $10.5455 / 2320-1770 . i j r \operatorname{cog} 20141201$

Cite this article as: Bagheri $\mathrm{A}$, Chianeh YR,

Kumar P, Rao P. Angiogenic factors in relation to embryo implantation. Int J Reprod Contracept

Obstet Gynecol 2014;3:872-9. 